\title{
The Effectiveness of Audiovisual Aids in Teaching Qur'anic Based-History
}

\author{
$1^{\text {st }}$ Wawan Hernawan ${ }^{1}, 2^{\text {nd }}$ Usep Dedi Rostandi ${ }^{1}$ \\ \{wanha99@yahoo.co.id', usep.dedi@uinsgd.ac.id ${ }^{1}$ \} \\ Faculty of Ushuluddin UIN Sunan Gunung Djati Bandung ${ }^{1}$
}

\begin{abstract}
This paper explains the effectiveness of audiovisual aids in teaching Qur'anic based-history of Islam. My object is the teaching of History of Islamic Civilization subject using DVD video for my students at Faculty of Ushuluddin, Islamic State University (UIN) Sunan Gunung Djati Bandung, using learning media approach. This research shows that the audiovisual aids is a very effective technique for improving the achievement of student learning. The effectiveness of audiovisual aids can be see from highly response rate of the students who agree to the use of audiovisual aids in teaching history of Islam (92.5\%); highly agree to the use of interactive DVD video (87.5\%); more easier to understand (82.5\%); in line with student expectations $(77.5 \%)$; and agree to recommend the use of audiovisual aids in teaching history of Islam $(72.5 \%)$. This study has implications for the research on technology of audiovisual in helping lecturer to develop their teachings for students of higher Islamic education in Indonesia
\end{abstract}

Keywords: audiovisual, DVD, technology,effecttiveness, teaching

\section{Introduction}

The information and communication technology rapidly depeloved in human activities. It is an increasingly creativity of human in their lives. One of their creativities is use of audiovisual aids in teaching activity [1]. There are many educational practitioners who used audiovisual for their teachings at school or university [2]. The use of audiovisual aids then raises their awarenesses to change the learning method, i.e. from teacher or lecturer centered to student centered, from conventional learning to internet-based learning (e-learning) and social media (e-mail, facebook, youtube, instagram, WhatsApp etc.) [3].

This study focuses on the effectiveness of audiovisual aids in teaching history of Islam in Islamic Higher Education. I used the audiovisual in the form of interactive DVD video entitled Potret Pribadi dan Kehidupan Rasulullah Saw., The personal portrait and life of the prophet Muhammad PBUH. It is a DVD video on history of Islam in Indonesia language which created by Ahmad Lutfi Fathullah. He is an expert of hadīth and sìra or biography of Muhammad who works at Hadith Studies Center of Al-Mughni at The Jakarta Islamic Center.[4] I will use the DVD video on history of Islam to help my students in learning History of Islamic Civilization subject at Faculty of Ushuluddin, Islamic State University (UIN) Sunan Gunung Djati Bandung. 
There are many scholars who have studied the audiovisual aids in teaching. Rasul, Bukhsh and Batool has proved the effectiveness of audiovisual aids in teaching learning process at university level [5]. Meanwhile, Haryoko already discussed the effectiveness of learning using audiovisual aids in teaching students at Electronic Engineering Department in Indonesia. He stated that the audiovisual aids can increase the student performance than ever before. According to Haryoko, the students who used audio-visual aids in his learning $(16,25)$ had higher performance than those used conventional learning $(9,25)$ [1]. I also found another case in Joni Purwono's research on the student ferpormance after used audiovisual aids in theirs learnings at secondary school SMP Negeri 1 Pacitan. Their learnings run very interactive and enthusiastic. The students become more motivated to continue their learnings. [6] Similar results were also found in Hasan's research on the use of audiovisual aids to achieve the student completeness of social sciences subjects (IPS) at the fourth grade elementary school SD Negeri 20 Banda Aceh [7]. Therefore, it is very significant to study the use of audiovisual aids in teaching Qur'anic based-history of Islam for students. This study not only highlights the effectiveness of audiovisual aids in the teaching and learning, but also shows that audiovisual aids have influence on the student performance in their learnings. In addition, this study is also important to improve the creativity of leacturers and students in learning Islamic history in Indonesia.

\section{Methodology}

This study uses the media of learning approach. I choose the method of Science, Technology, and Society (STS) [8]. It is a combination of conceptual approach, process skills, inquiry and discovery, and environmental approach. The philosophy of STS approach is the assumption that students constructed their own concepts within their cognitive structures based on what they already knew. The STS approach is considered appropriate not only to increase students performance, but also to study the use of audiovisual aids in teaching history of Islam.

I used the audiovisual aids in the form of interactive DVD video in Indonesia language which created by Ahmad Lutfi Fathullah. The DVD video contains twenty fourmajor historical life themes of Muhammad, i.e. the history of Muhammad's birth, his name and alias, Muhammad's family, his friends, his physicalform, cloths, foods, historicplaces of Muhammad, and the responseof scholars to the prophet. This DVDvideo is in the form of a disk circle with $12 \mathrm{~cm}$ diameter. It is coveredby paper and plastic material $(19 \mathrm{X} 13.5 \mathrm{~cm})$. The titile of cover is written in Indonesian and Arabic. The DVD video was first launched in 2010 and then reproduced in 2013.

I used audiovisual aids in teaching history of Islam for my students as population. They are students who studied currently at semester II, IV and VI, Qur'anic Studies and Tafsir Department (IAT) and Islamic Mysticism and Psychotherapy Department (TP). I also used the technique of simpe random sampling. It is a technique which stated that each individual in the population has the same opportunity to be elected as a sample. The sample is determined randomly. I take forthy students from three different classes as a sample. They are proposed to answer some questions using Whatsapp. I used rating satisfaction scale of five answersthat must be choosed by respondents (excellent, very good, good, fair, poor). Following table shows the profile of respondents:

Table I

Profile Of Respondents 


\begin{tabular}{|c|l|c|c|c|c|c|c|}
\hline No & \multicolumn{7}{|c|}{ Profile of respondents } \\
\hline 1. & Sex & M & $12 / 30 \%$ & F & $28 / 70 \%$ & - & - \\
\hline 2. & Age & $<20$ & $4 / 10 \%$ & $>20$ & $36 / 90 \%$ & - & - \\
\hline 3. & Department & IAT & $36 / 90 \%$ & TP & $4 / 10 \%$ & - & - \\
\hline 4. & Semester & II & $4 / 10 \%$ & IV & $29 / 72,5 \%$ & $\mathrm{VI}$ & $7 / 17,5 \%$ \\
\hline
\end{tabular}

I used interactive DVD video in classrom for every session usingslide of projectors. There are two or three sessions of DVD video show for every semester. It is not all contents of history of Islam in DVD video can be showed. Every student are expected study the history of Islam.

\section{Result and Discussion}

\section{A. The steps of audiovisual aids in teaching}

Audiovisual is one of product of technologies that often used in education [9]. It means possesing both a sound and a visual component [2]. There are two kinds of audiovisual: silent and motion audiovisual. Silent audiovisual or impure audiovisual is an audiovisual which sound and visual component derived from another source, such as a sound frame film which itsvisualcomponent is derived from the slide of the projector and the sound component is derived from a tape recorder. Meanwhile, motion or pure audiovisual is both sound and visual components derived from a single source, such as a video cassette film [1]. The interactive DVD video which created by Ahmad Lutfi Fathullah can be regarded as a silent or impure audiovisual.

The audiovisual aids in teaching has many steps as in other media of learning. I used three steps in the use of audiovisual aids in teaching: preparation, implementation, and follow-up stage. First, the preparation stage will include the plan of learning activity, studying manual instruction on audiovisual aids, and preparing audiovisual component that will be used. Second, the implementation stage of learning activities have to consider that the audiovisual aids and all equipment in teaching are complete and ready to use; to explain the objectives of learning that must to be achieved; to explain the subject to the students during the learning process; and to avoid the situations that can disturb the concentration of students. Third, the follow-up stage haveto be done to strengthen students' understanding of the subject that has been learned. This last activityaims to measure the effectiveness of learning that has been implemented [9].

\section{$B$. The response of the studentsto audiovisual aids in teaching}

This section will highlights the answers of respondents in the form of questionnaires that have been collected. I used rating satisfaction scale of five answers that must be choosed by respondents (excellent, very good, good, fair, poor). 
(1) Do you agree that audiovisual aids in teaching can help your understanding?

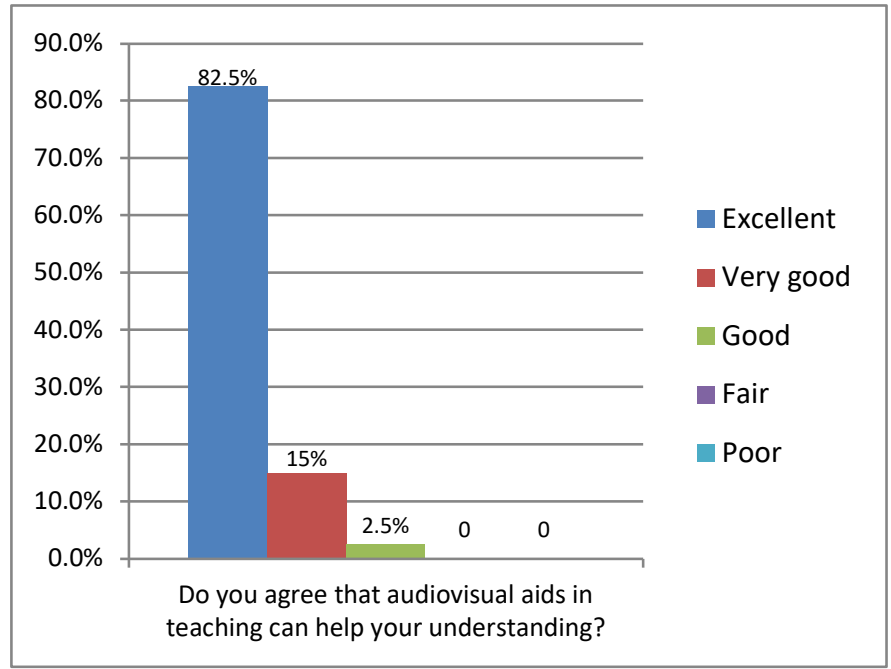

Fig. 1. Result of questions 1

(2) Do you agree to audiovisual aids in teaching of Qur'anic based-history of Islamic civilization?

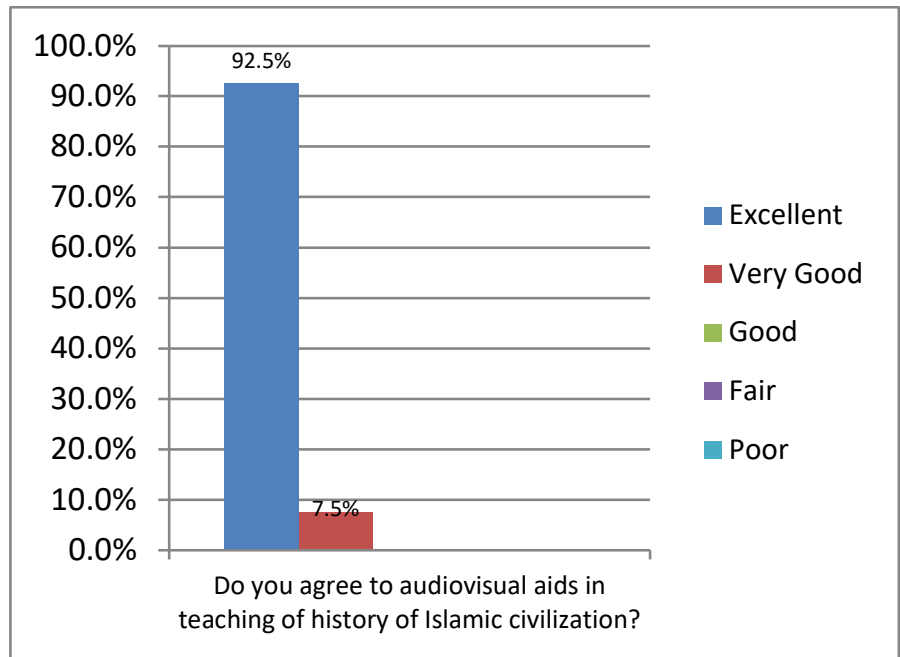

Fig. 2. Result of questions 2 
(3) Do you agree with the use of Fathullah's DVD video in the teaching Qur'anic basedhistory of Islamic civilization?

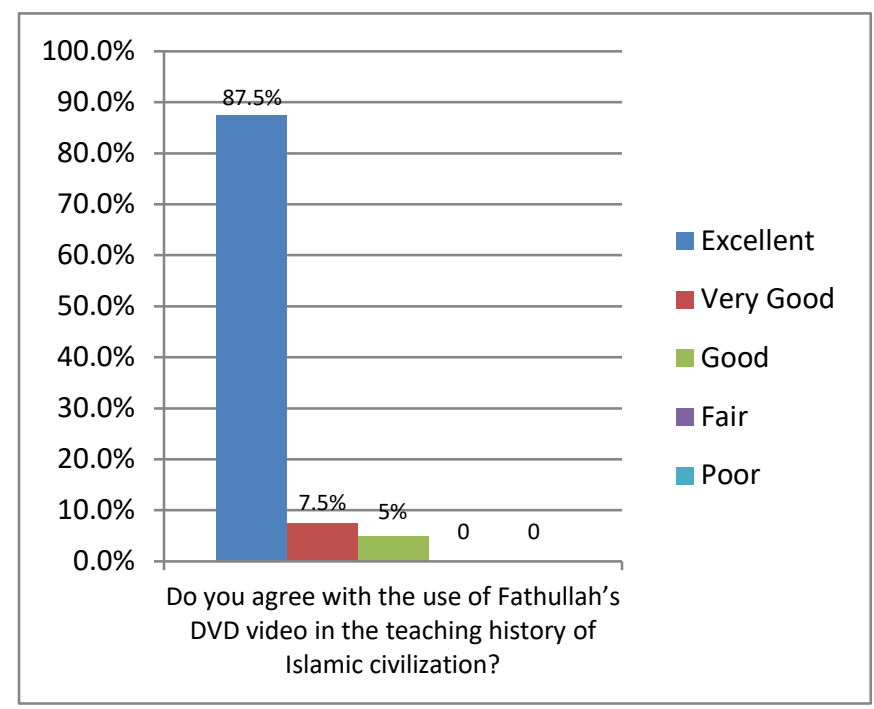

Fig. 3. Result of questions 3

(4) Is the subject of Fathullah's DVD video wishes fullfilled?

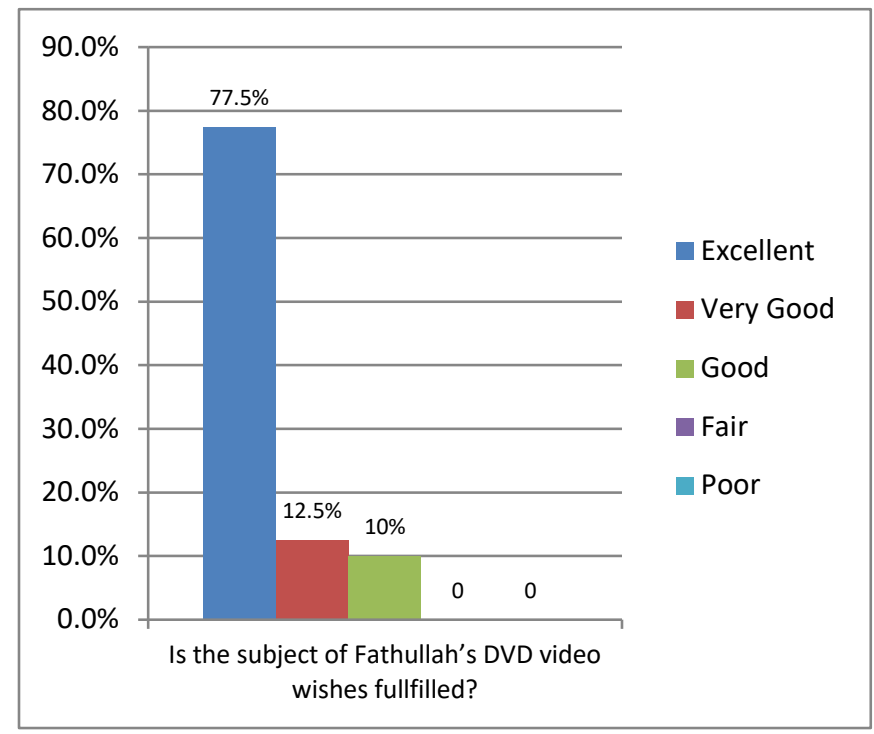

Fig. 4. Result of questions 4 
(5) Will you suggest to your lecturer to use Fathullah's DVD video in the teaching of Qur'anic based-history of Islamic civilization?

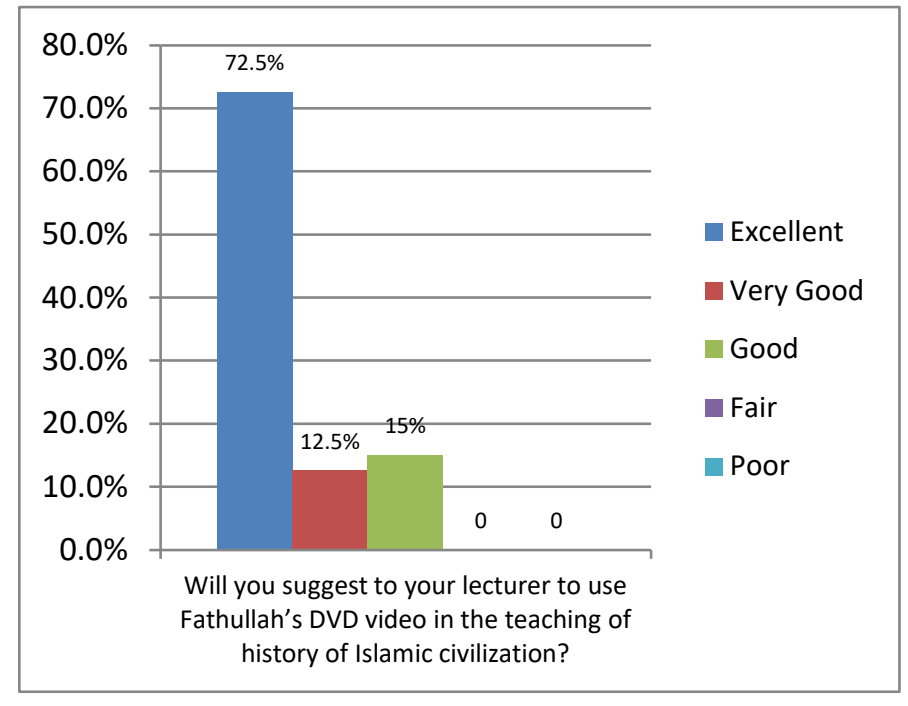

Fig. 5. Result of questions 5

Based on the above answers, the audiovisual aids has influenced the effectiveness of teaching Qur'anic based-history of Islam. The students agree to use audiovisual aids. There are excellentrating satisfaction scale from $72.5 \%$ to $92.5 \%$. Meanwhile, bothfair and poor rating satisfaction scale are $0 \%$. It can be said that the students strongly agree to use audiovisual aids in teaching Qur'anic based-history of Islam. They mostly agree to suggest interactive DVD video which created by Fathullah.

\section{CONCLUSION}

The effectiveness of audiovisual aids in teaching Qur'anic based-history of Islamic civilization indicated very good response from the students. They mostly do not deny the use of audiovisual aids in teaching. The effectiveness of audiovisual aids can be see from highly response rate of the students who agree to the use of audiovisual aids in teaching Qur'anic based-history of Islam (92.5\%); highly agree to the use of interactive DVD video (87.5\%); more easier to understand (82.5\%); in line with student expectations (77.5\%); and agree to recommend the use of audiovisual aids in teaching Qur'anic based-history of Islam (72.5\%).

\section{References}

[1] Sapto Haryoko, "Efektivitas Pemanfaatan Media Audio-Visual sebagai Alternatif Model Pembelajaran”dalam Jurnal Edukasi @Elektro, Vol. 5 No. 1, pp. 3, (Maret 2009).

[2] Wina Sanjaya, Strategi Pembelajaran Berorientasi Standar Proses Pendidikan. Jakarta: Kencana, 2010. 
[3] Fatimah Husein dan Martin Slama, "Online Piety and Its Discontent: Revisiting Islamic Anxieties on Indonesian Social Media" dalam Indonesia and The Malay World, Vol. 46, No. 134, pp. 80; 93, (Februari 2018).

[4] Ahmad Lutfi Fathullah "Tentang Program" dalam DVD Interaktif Potret Pribadi dan Kehidupan Rasulullah Saw. Jakarta: Pusat Kajian Hadis Al-Mughni Center, 2013.

[5] Saima Rasul, Qadir Bukhsh, Shazia Batool, "A study to analyze the effectiveness of audio visual aids in teaching learning process at university level," Procedia, Social and Behavioral Sciences, 28 (2011), 78-81.

[6] Joni Purwono, at al, "Penggunaan Media Audio-Visual pada Mata Pelajaran Ilmu Pengetahuan Alam di Sekolah Menengah Pertama Negeri 1 Pacitan" dalam Jurnal Teknologi Pendidikan dan Pembelajaran, Vol.2, No.2, pp. 129-130 (April 2014).

[7] Hasmiana Hasan, "Penggunaan Media Audio Visual Terhadap Ketuntasan Belajar IPS Materi Perkembangan Teknologi Produksi, Komunikasi, dan Transportasi pada Siswa Kelas IV SD Negeri 20 Banda Aceh" dalam Jurnal Pesona Dasar, Vol. 3 No.4, pp. 22 - 33, (Oktober 2016).

[8] Sabar Nurohman, "Penerapan Pendekatan Sains-Teknologi-Masyarakat (STM) dalam Pembelajaran IPA sebagai Upaya Peningkatan Life Skills Peserta Didik " dalam Majalah llmiah Pembelaiaran No. 1, Vol. 2, pp. 59-63, (Mei 2006).

[9] Azhar Arsyad, Media Pembelajaran. Jakarta: Raja Grafindo Persada, 2011. 